\title{
Reading Skill Improvement Through Visual Memory, Question, Read, Recite, Record, and Review English Instructional Method (VMQ4R-EIM)
}

\author{
(A classroom action research (CAR) in one of Indonesia Secondary School)
}

Noldy Pelenkahu, Donald M. Ratu

Manado State University, North Sulawesi, Indonesia

\begin{abstract}
To improve students' reading skill through VMQ4R-EIM and to reflect the English instructional process implemented by the teacher in the secondary school, and finally the teacher can introspect his English instructional activities, there are 40 students as the research subjects of this CAR (classroom action research) and it used spriral method from Kemmis and McTaggart with four stages (plan, action, observation, reflection). The research result showed that there was significant reading skill improvement to secondary school students. In the first cycle, the student's reading skill improved to $62 \%$ and the observation result reached to $65 \%$. In the second cycle, the student reading skill improved to $97 \%$ and the observation result reached to 95\%. The VMQ4R-EIM can improve secondary school students' reading skill. The research implication is the VMQ4R-EIM that is one way to be implemented by the English teacher in order to improve and make the students motivated and active in attending the instructional process.
\end{abstract}

Keywords: reading skill, VMQ4R-EIM

\section{Rationale}

English instruction in secondary school must give opportunity to students for doing many things for enriching their comprehension and motivation in learning process. It is also important for English teachers to face globalization competitiveness because English is the need to develop knowledge, technology and to communicate globally. This means that by learning English well one can open his thought globally.

The objection of English instruction in secondary school is to give student skills (listening, speaking, reading, and writing). These English skills cannot be taught separately. They are taught integratively and support each other. But, on the assumption that reading is not important, however through reading one can get information and other knowledge and technology. So reading must be taught early in order that the students can be active and habitually do reading in daily life. Reading habit must be the important act for improving one's life quality. One action of reading is to do visual memory. Here, a student does reading using his visual memory by functioning his eyes to understand what he is reading.

Noldy Pelenkahu, FBS, Universitas Negeri Manado, Indonesia.

Donald M. Ratu, English Department, Manado State University, North Sulawesi, Indonesia. 
Reading by using visual memory has the same objection with reading comprehension. It is divided into extensive reading and intensive reading. Reading comprehension is the part of intensive reading which objects to comprehend the reading content. The one ability to comprehend symbols, marks, or writing and the ability to connect the writing which he is reading with his schemata (early knowledge and experiences) can help him to understand the reading materials.

Reading by visual memory is useful for students to learn any subject matters at school. The skill of reading by visual memory is being the act to get information from the reading text. Indicators of reading achievement by visual memory are: (1) to get the reading main idea; (2) to identify information; (3) to get the main ideas and their descriptions; (4) to tell again the reading content; and (5) to describe messages which are presented in reading text. But, the factors affect the skill are: (1) The student has less interest in reading; (2) the student is not concentrated when reading; and (3) less of vocabulary belongs to the student. Secondary school students always face difficulties to read English because there is different spelling with Indonesian. That is why teachers have to be able to be the facilitator for guiding students and making them experience to do reading by visual memory. So VMQ4R-EIM is being one effective method in helping students to improve their reading skill. There are six steps to implement this instructional method. They are: (1) pre-reading, (2) question, (3) read, (4) recite, (5) record, and (6) review.

Richards, Regina G. (2018) stated that we are all using strategies throughout our day to remember the variety of facts and ideas we need to retain. It is valuable for teachers, therapists, and parents to understand the memory process in order to become better equipped to help our students understand and use strategies. Strategy use forms a critical part of our learning experience. Strategies help us organize information into patterns and encourage purposeful learning.

The problem is "How to improve the student reading skill through VMQ4R-EIM? Theoretically, the research can be useful to develop English instruction, especially to implement the method and as the one solution alternative to improve the student reading skill. Practically, the research can be useful to students, which hopes to improve the reading skill and to get experiences. To the teachers, it can implement as the instructional lesson to improve students' reading skill through VMQ4R-EIM. And to the researcher, it can be the reference materials in investigating classroom phenomenon correlated to English instruction, especially the improvement of reading skill through VMQ4R-EIM. To the next research, it is the information to improve English achievement in secondary school by implementing VMQ4R-EIM.

\section{Research Design and Theory}

The participants involved in this research are the researcher who has the role as the planner of the action collaborates and the eighth grade student English teacher. So the intervention stages which will be done are based on the research problem which will be solved. The researcher plans the research as cycle one, two, and three. If in the cycle two the target is not yet reached from the target determined, it will continue to cycle three. Each cycle consists of plan, action, observation, and reflection stages as the basic of development to the next cycle. The following Figure 1 describes the CAR design of the research. 

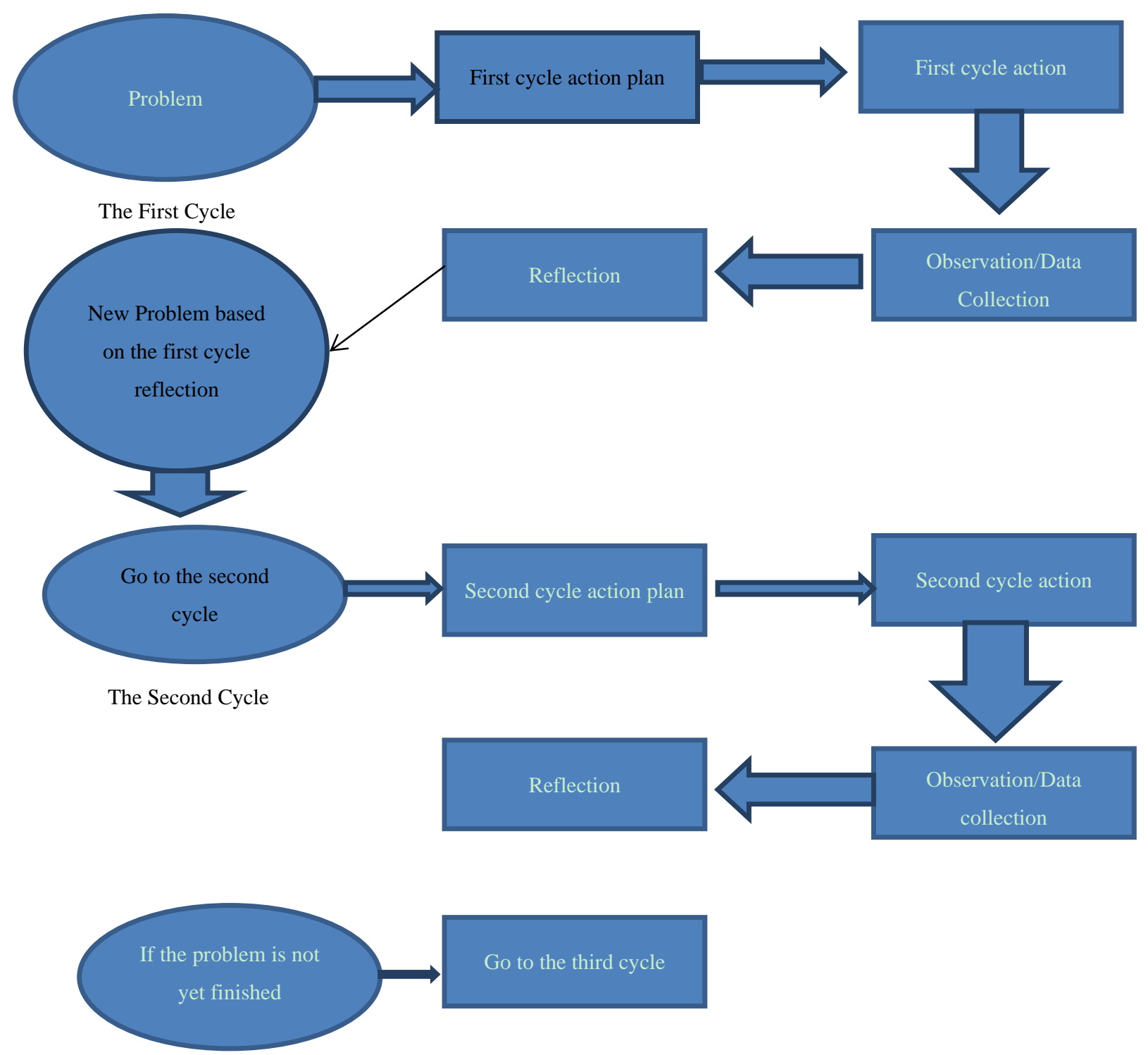

Figure 1. The CAR design of the research.

The improvement of reading skill is shown from student test sheet on each end cycle. The student achievement is stated in form of score reaching of $70 \%$. And in order to know the teacher successful of implementing the VMQ4R-EIM, the researcher together with collaborator observed the instructional process with the achievement indicator of reaching $90 \%$. The instrument of the CAR in form of observation sheet prepared by teacher, observation sheet of instructional process, and observation sheet of recording data which were not yet found in the instrument. Data source is the action observation of the teacher activities in English instructional process of reading skill.

Visual memory reading skill is one skill to involve various activities actively through visual memory which involves the eyes activity, remembering, and it can be able to find and comprehend information in reading text and then to tell again the reading content by using self words suitable with the students' comprehension. The visual memory instrument framework of reading skill is described in the following table below (see Table 1). 
Table 1

The Reading Skill Visual Memory Instrument Framework

\begin{tabular}{llll}
\hline \multirow{2}{*}{ Indicator } & \multicolumn{2}{c}{ Item type } & Item sum \\
\cline { 2 - 4 } & Multiple choice & Essay & 5 \\
Determine main idea of the text & $\mathrm{V}$ & - & 3 \\
Determine the important detail & $\mathrm{v}$ & - & 2 \\
Determine the main idea and its description & $\mathrm{v}$ & - & 1 \\
Describe the messages which presenting in the reading text & - & $\mathrm{v}$ & 1 \\
Comparing the reading materials & - & $\mathrm{v}$ & 2 \\
Conclude the reading materials & - & $\mathrm{v}$ & 1 \\
To tell again the reading content in written style & - & $\mathrm{v}$ & 15 \\
Sum & 10 & 5 & \\
\hline
\end{tabular}

VMQ4R-EIM is a part of English instructional method which systematically consists of six steps implementation, such as pre-reading, question, read, recite, record, and review. It objects to help students to comprehend the reading text content. The following table (see Table 2) described the teacher and student observation acts instrument with the implementation of VMQ4R-EIM.

Table 2

The VMQ4R-EIM Teacher and Student Observation Acts Instrument

\begin{tabular}{|c|c|c|c|c|}
\hline \multirow{2}{*}{ Dimension } & \multirow{2}{*}{\multicolumn{2}{|c|}{ Item number }} & \multicolumn{2}{|l|}{ Indicator } \\
\hline & & & Teacher & Students \\
\hline \multirow{3}{*}{ Pre-reading } & 1 & 11 & Doing instructional process suitable with the indicator & Ready to do instructional process \\
\hline & 2 & 12 & $\begin{array}{l}\text { Tell the instructional topic and doing } \\
\text { scafolding/aperception }\end{array}$ & $\begin{array}{l}\text { Question and answer to teacher about } \\
\text { the instruction topic }\end{array}$ \\
\hline & 3 & 13 & $\begin{array}{l}\text { The teacher guide students in doing pre-reading. Here the } \\
\text { teacher observed students to read the text and discuss the } \\
\text { new vocabulary }\end{array}$ & $\begin{array}{l}\text { Doing pre-reading acts such as to } \\
\text { observe the text and discuss the new } \\
\text { vocabulary }\end{array}$ \\
\hline Questions & 4 & 14 & Guide students to ask questions & Do the question stage \\
\hline Read & 5 & 15 & $\begin{array}{l}\text { Guide students to read with good spelling and then facilitate } \\
\text { students to read (visual memory act) }\end{array}$ & $\begin{array}{l}\text { Do the read stage (reading aloud) and } \\
\text { then to do visual memory act }\end{array}$ \\
\hline Recite & 6 & 16 & Guide students to recite, that is to answer the questions & Answer the questions \\
\hline Record & 7 & 17 & $\begin{array}{l}\text { Guide students to record, that is to mark or underline the } \\
\text { answers in the reading content }\end{array}$ & $\begin{array}{l}\text { To record by marking and underlining } \\
\text { the answers in the reading text content }\end{array}$ \\
\hline \multirow{3}{*}{ Review } & 8 & 18 & $\begin{array}{l}\text { Guide students to review, such as presenting or reading } \\
\text { their answers }\end{array}$ & $\begin{array}{l}\text { Presenting the answers to teacher and } \\
\text { other students }\end{array}$ \\
\hline & 9 & 19 & $\begin{array}{l}\text { Confirm student ability in implementing VMQ4R-EIM for } \\
\text { reading comprehension which they had been studying from } \\
\text { the tasks and fulfill the reading comprehension test }\end{array}$ & $\begin{array}{l}\text { Do the tasks and the reading } \\
\text { comprehension test }\end{array}$ \\
\hline & 10 & 20 & Giving feedback (reinforcement, tasks given or homework) & Doing the reinforcement or the tasks \\
\hline Sum & 10 & 20 & & \\
\hline Total & & 20 & & \\
\hline
\end{tabular}

Notes. Each activity which is reached get the score $=1$; Each activity which is not reached get the score $=0$; Total score $=20$;

Percentage = --------------------------------- $\times 100 \%$

The formula for reading skill result data of visual memory which got $95 \%$ is as the following.

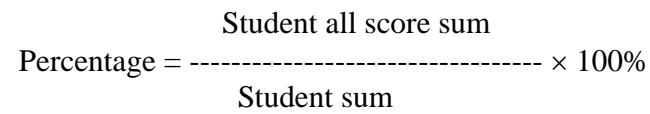

The formula for VMQ4R-EIM action observation data which got $90 \%$ is as the following.

$$
\begin{gathered}
\text { Peaching score sum } \\
\text { Percentage }=\text {------------- } \times 100 \%
\end{gathered}
$$




\section{The Nature of Visual Memory Reading}

Visual memory reading is total score which belongs to students based on the activities for gathering information or messages in the way to comprehend a reading text. The learning achievement indicators consist of: (1) to find out the main idea, (2) to identify information, (3) to find the main idea and it description, (4) to tell again the reading content, and (5) to describe messages which are presented in the reading text. From these five indicators, usually the instructional process can be designed in order to improve some students' reading skill (Brown, 2007, p. 84). And through visual memory reading, students reach the speed of comprehension to phrases, enrich vocabulary, and get the strength in habitual with good literature (Cole, 1979, p. 31). So visual memory reading is the reading activity which is done without voice of reading content and only uses visual memory that involves eyes activity and remembering. In this way, the active is the eyes and remembering. By visual memory reading, the reader can know and comprehend new vocabulary and then gets information from the reading text.

Visual memory is to practice students to get reading meaning in short time and to practice their ability to focus their thought on one item and then to get conclusion for what is reading (Cole, 1979). The students' visual memory reading skill is so supported by their reading experiences and knowledge in mastering the linguistic knowledge, such as vocabulary and grammar. So the ability in visual memory reading is to response the writing construction reflectively faced or which is simulated. The response presenting is the active response. This active response related to the organizing of the writing construction. Visual memory reading is being one of the reading types which is useful to comprehend ideas that are consisted in the reading itself to its detailed elements. The visual memory reading is being important thing for introducing students to the reading world. And this is not formed easily, so the development psychologists found a concept about how to introduce students to the good way of doing reading. So visual memory reading is related to the students' souls.

Effective and efficient memory is critical for reading and school success. The memory demands for school-age children are much greater than they are for adults. As adults, we have already acquired much of the knowledge and skills we need to function day to day. Although the knowledgebase for some fields such as technology changes rapidly, the new information is generally highly specific and builds on existing knowledge. On the other hand, school children are constantly bombarded with new knowledge in multiple topic areas which they may or may not be interested. Additionally, they are expected to both learn and demonstrate the mastery of this knowledge on a weekly basis. Thus, an effective and efficient memory is critical for school success. The following ten general strategies are offered to help students develop a more efficient and effective memory. They are: (1) give directions in multiple formats; (2) teach students to over-learn material; (3) teach students to use visual images and other memory strategies; (4) give teacher-prepared handouts prior to class lectures; (5) teach students to be active readers; (6) write down steps in math problems; (7) provide retrieval practice for students; (8) Help students develop cues when storing information; (9) prime the memory prior to teaching/learning; (10) review material before going to sleep. (Thorn, Glenda. $2018 . \quad$ In http://www.readingrockets.org/article/10-strategies-enhence-students...) retrieved March 22/2018, 10:22 AM.)

In the context of question, teachers can do a lot to encourage higher order thinking, even when they are answering children's questions. Robert Sternberg in Alice Thomas and Glenda Thorn (2018) answered to children's questions, which can be categorized into seven levels, from low to high, in terms of encouraging higher levels of thinking. While we would not want to answer every question on level seven, we would not want to answer every question on levels one and two, either. The different levels of the questions are: (1) reject the question; (2) restate or almost restate the question as a response; (3) Admit ignorance or present information; (4) voice encouragement to seek response through authority; (5) encourage brainstorming or consideration of 
alternative explanations; (6) encourage consideration of alternative explanations and a means of evaluating them; and (7) encourage consideration of alternative explanation plus a means of evaluating them, and follow-through on evaluations (Thomas \& Thorn, 2018).

\section{The Nature of VMQ4R-EIM}

VOMQ4R-EIM is one of reading methods for comprehending reading content by using systematical stages in its implementation. It is a reading type which needed one to ask suitable information consists in a reading text which tasks that must be finishing. Reading with VMQ4R-EIM consists of pre-reading, question, read, recite, record, and review. It gives strategy stated from developing general description about instructional materials which will be or still learning, motivating questions from title or subtitle of a chapter, continues to read for looking for answers from the questions until getting the level comprehending which will reach more deeper because the reader reads actively until the reading process is more effective and efficient.

In implementing this reading method, of course the reader needs to determine first his reading objection. Besides that, the reader also determines the focus information needed. After that, the reader uses the VMQ4R-EIM to get information needed. In this case, the reader who uses this method must follow each stage which has been stated, that is before reading, the reader must do pre-reading first of the book, chapters, article, clipping, or empirical journal which he or she is reading. After reading, the reader determines what will be read and he has to ask questions about the information from the finding result while pre-reading. Continuously, the reader reads the information needed. Then, the reader has to be able to tell again what he or she is reading by using his own language. In order to know what had been told orally or written and had been suitable with the reading content is reading, so in implementing this method, the reader has to read again what is reading, so he can know what had been presented had been suitable with the reading content is reading. And if it is not yet suitable or still there is important thing which is not yet presented, the reader can make correction until the comprehensive result will be got.

The VMQ4R-EIM characteristics are: (1) before reading, the reader does pre-reading first of the book title, the author's name, summary, and the bibliography; (2) constructs some questions for himself about the reading which hoping the answers are in the book; (3) based on the questions, the reader starts the reading activity; (4) in order to know the mastering of the reading, after reading, the reader does the act to say again the reading content with the own words; and (5) the reading activities with VMQ4R-EIM are finished with the act to review again or to say again what has been read. These characteristics put students to be more creative in developing their reading skill, especially in visual memory reading.

The VMQ4R-EIM stages are pre-reading, question, read, recite, record, and review.

(1) Pre-reading stage is a technique to know materials before reading completely. It is done to know the organization which will be read in order to: (1) quickly get the meaning; (2) to get abstract; (3) to know the important ideas; (4) to see the reading materials organized; (5) to get attention to the reading text; and (6) to make it easy to remember more and to comprehend easily.

(2) Questions stage, while pre-reading stage, ask many questions about the reading content with to change the title and subtitle to be a question. Use the question words of "where" or "why". In time to do pre-reading, generally the questions are in general, but in time to do pre-reading to chapter to chapter and the questions can be more specific. A question can develop some another questions about the reading content deeper. As there are various questions, the reading way will be more active and easier to gather ideas besides to read only. 
(3) Read stage: Start to read the reading text part to part. While reading the parts, look for the answers of the questions which were formed based on the part title or other questions which are related to the reading topic. In this stage, concentrate to master the main idea and the details which are important to support the main idea. Be slowly the students ways of reading in parts which are important or which had been known.

(4) Recite stage: Now stop a while and think again of what had been investigated before. See again the notes which had been done and remember again the main ideas which had been noted. The other way to do recite is to see the questions which had been constructed before reading subchapter and try to answer them without seeing the book or the discourse again. Basically, to recite objects to present again the various information, such as answers of the questions, and the other information which we think important, make summary, and conclude what had been read suitable with the reader version.

(5) Record stage: Here the reader makes notes from the reading materials. It can be done in the following way: After reading the part from the reading materials, reflect and construct questions about it, now you are ready to write. To write in this time is to justify that you remember the important parts of the reading materials; read again the paragraphs and underline or mark the main ideas and the supporting ideas. Make sure that you are only to underline or mark not more than $10-15 \%$ from the pages of the reading materials. Use marginal notation as the way to separate the main ideas from samples and from the new terminologies.

(6) Review stage: Check again the whole parts, do not read again, only to see the titles, figures, and diagrams, review again the questions and studying facilities for making sure that it had a complete description about the reading materials. This stage will give many helps in remembering the reading materials so it can be easy to remember in the class and to present again in the exam session. Shortly in the review stage is applied testing or reviewing about the completion of presenting again what we had been done in recite stage. So if there is incompleteness and if there are mistakes, please be corrected. Finally, it can construct the information structure which if they can be developed, so it can form the nature of presenting again completely and wellness. Review stage is very important because in time to read, generally it can master the $85 \%$ information from the reading content, and then in time of eight hours to remember which still only $35 \%$ details and in time of two weeks, the reading comprehension still $20 \%$.

\section{The Research Finding and Discussion}

Based on the observation and discussion between the researcher and collaborator, it was found that there were still weaknesses and problems to the English instructional activities. The students were not active along the instructional process, they were not inaccurate to do the tasks given by the teacher and they were not be brave or confident and concentrated to attend the instructional process, so they did not get the target score of achievement. The teacher did not also elaborate the student ability in applying the VMQ4R-EIM and was always hasty or in a hurry to go to the next activities in instructional process. And then the mean score of reading skill test got by the students was not achieved the target of $75 \%$.

The following Table 3 describes the visual memory test of the student's reading skill. 
Table 3

The Student' Reading Skill Score Based on the Visual Memory Act of the First Cycle

\begin{tabular}{|c|c|}
\hline Student code & Score achieved \\
\hline$\overline{S s 1}$ & 85 \\
\hline Ss2 & 75 \\
\hline Ss3 & 75 \\
\hline Ss4 & 75 \\
\hline Ss5 & 65 \\
\hline Ss6 & 65 \\
\hline Ss7 & 75 \\
\hline Ss8 & 55 \\
\hline Ss9 & 80 \\
\hline Ss10 & 75 \\
\hline Ss11 & 65 \\
\hline Ss12 & 75 \\
\hline Ss13 & 85 \\
\hline Ss14 & 75 \\
\hline Ss15 & 85 \\
\hline Ss16 & 95 \\
\hline Ss17 & 45 \\
\hline Ss18 & 85 \\
\hline Ss19 & 65 \\
\hline Ss20 & 55 \\
\hline Ss21 & 85 \\
\hline Ss22 & 85 \\
\hline Ss23 & 95 \\
\hline Ss24 & 45 \\
\hline Ss25 & 85 \\
\hline Ss26 & 90 \\
\hline Ss27 & 75 \\
\hline Ss28 & 75 \\
\hline Ss29 & 65 \\
\hline Ss30 & 85 \\
\hline Ss31 & 75 \\
\hline Ss32 & 55 \\
\hline Ss33 & 65 \\
\hline Ss34 & 45 \\
\hline Ss35 & 45 \\
\hline Ss36 & 85 \\
\hline Ss37 & 55 \\
\hline Ss38 & 75 \\
\hline Ss39 & 45 \\
\hline Ss40 & 45 \\
\hline Sum score & 2830 \\
\hline Mean score & 70.75 \\
\hline Percentage score achieved & $62 \%$ \\
\hline Target score achieved & $75 \%$ \\
\hline
\end{tabular}

Based on the action intervention above, it was concluded that the implementation of VMQ4R-EIM in first cycle was not optimal yet, so the researcher and collaborator justified continuing to the second cycle. In the second cycle, the weaknesses and the problems faced in the first cycle were successful to tacle and corrected. In this cycle, the teacher was successful to motivate students to be able to ask questions and give description more 
clearly and details and to elaborate the student's ability to implement the VMQ4R-EIM. They were practiced to spell English well. The following Table 4 describes the student's reading skill score based on the visual memory act of the second cycle.

Table 4

The Student' Reading Skill Score Based on the Visual Memory Act of the Second Cycle

\begin{tabular}{|c|c|}
\hline Student code & Achieved score \\
\hline Ss1 & 85 \\
\hline Ss2 & 75 \\
\hline Ss3 & 75 \\
\hline Ss4 & 75 \\
\hline Ss5 & 65 \\
\hline Ss6 & 65 \\
\hline Ss7 & 75 \\
\hline Ss8 & 55 \\
\hline Ss9 & 80 \\
\hline Ss10 & 75 \\
\hline Ss11 & 65 \\
\hline Ss12 & 75 \\
\hline Ss13 & 85 \\
\hline Ss14 & 75 \\
\hline Ss15 & 85 \\
\hline Ss16 & 95 \\
\hline Ss17 & 45 \\
\hline Ss18 & 85 \\
\hline Ss19 & 65 \\
\hline Ss20 & 55 \\
\hline Ss21 & 85 \\
\hline Ss22 & 85 \\
\hline Ss23 & 95 \\
\hline Ss24 & 75 \\
\hline Ss25 & 85 \\
\hline Ss26 & 90 \\
\hline Ss27 & 75 \\
\hline Ss28 & 75 \\
\hline Ss29 & 85 \\
\hline Ss30 & 85 \\
\hline Ss31 & 75 \\
\hline Ss32 & 55 \\
\hline Ss33 & 65 \\
\hline Ss34 & 45 \\
\hline Ss35 & 75 \\
\hline Ss36 & 85 \\
\hline Ss37 & 55 \\
\hline Ss38 & 75 \\
\hline Ss39 & 75 \\
\hline Ss40 & 45 \\
\hline Sum score & 2940 \\
\hline Mean score & 73.50 \\
\hline Percentage score achieved & $97 \%$ \\
\hline Target score achieved & $75 \%$ \\
\hline
\end{tabular}


The following Table 5 described the comparison of visual memory reading test result score achieved between the first and second cycle.

Table 5

The Visual Memory Reading Test Result Score Achieved Comparison Between First and Second Cycle

\begin{tabular}{llll}
\hline Item & First cycle score achieved & Second cycle score achieved & Target score \\
\hline The lowest score & 45 & 45 & \\
The highest score & 95 & 95 & \\
Sum & 2830 & 2940 & $75 \%$ \\
Mean score & 70.75 & 73.50 & \\
Percentage of students & $65 \%$ & $97 \%$ & \\
achieved score & & & \\
\hline
\end{tabular}

And according to the observation result of the teacher and students activities in the first cycle, it was found that the percentage of the observation result of the teacher and students activities by using VMQ4R-EIM did not yet reach to $90 \%$ and it only reached to $65 \%$. However, in the second cycle, it reached to $100 \%$. This is described in the following Table 6 bellow.

Table 6

VMQ4R-EIM First and Second Cycle Teacher and Students Activities Observation Percentage

\begin{tabular}{ll}
\hline Cycle & VMQ4R-EIM teacher and students activities observation \\
\hline The first action implementation in first cycle & $60 \%$ \\
The second action implementation in first cycle & $65 \%$ \\
The first action implementation in second cycle & $80 \%$ \\
The second action implementation in second cycle & $95 \%$ \\
\hline
\end{tabular}

Based on the above research result analysis interpretation, it can be said that the improvement of the result score in the second cycle comparing with in the first cycle of the student's reading skill; it was found that the implementation of VMQ4R-EIM is being successful. The VMQ4R-EIM implementation by the teacher in improving the student's reading skill is being the affordance to develop the creativity and innovation in designing the instructional process of the VMQ4R-EIM. That is why the VMQ4R-EIM can be one of the instructional methods of teaching reading skill in English subject matter.

\section{Conclusion}

Based on the research result and discussion, it can be concluded that by implementing VMQ4R-EIM, the student's reading skill improve to $65 \%$ in first cycle and $97 \%$ in second cycle. It means that by using VMQ4R-EIM in English instructional process, the students can be easy to understand the reading text and generally, the reading instruction with VMQ4R-EIM gives more impact to the reading skill result, so it must be used by the teacher in teaching secondary school students. And then, by using VMQ4R-EIM, students can think systematically following the stages of it.

\section{Implication}

The instructional process applied by the teacher will be more effective if he/she can choose and use strategy, method or approach, and instructional model suitable with the students' characteristics. The VMQ4R-EIM should be implemented in teaching English if the teacher experiences difficulties and achieves 
low score in reading skill. This can impact positive learning process to students who do not interest, and then they can understand the reading text more and remember the reading content. The strengths of this instructional method are that it can be implemented comprehensively and the students' achievement will be the knowledge and concepts which can be useful to them.

\section{Suggestion}

Based on the conclusion and implication, it can be suggested the following:

(1) The principle of the secondary school should be asked to all English teachers for implementing in teaching English subject matter. It must be materials for planning, implementing, development, and improving the school quality, especially in English instructional process;

(2) The teachers must implement this method effectively and efficiently in order that the students will be more motivated to learn English, especially in reading activities. This method is suitable to English instructional process because it can improve the students' reading skill.

\section{Reference}

Brown, H. D. (2007). Prinsip Pembelajaran dan Pengajaran Bahasa. (N. Cholis \& Y. A. Pareanom, Trans.). USA: Pearson Education.

Cole. (1979). Membaca sebagai suatu keterampilan berbahasa. Bandung: Angkasa. Retrieved December 20, 2017 from http://www.abdan-syakuro.com/2014/02/jenis-jenis-membaca-menurut.para:ahli.html http://www.indopos.co.id/2013/12/bahasa-inggris-jadi-muatan-lokal-baru.html

De Porter, B., \& Hermacki, M. (2002). Quantum learning. Bandung: Kita Press.

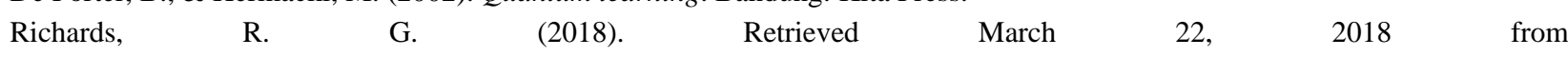
http://www.readingrockets.org/article/making-it-stick-memorable-strategy

Thorn, G. (2018). Retrieved March 22, 2018 from http://www.readingrockets.org/article/10-strategies-enhence-students

Thomas, A., \& Thorn, G. (2018). How to increase higher order thinking. Retrieved March 22, 2018 from http://www.readingrockets.org/article/how-increase-higher-order-thinking 